\title{
Creole in Mauritius
}

Keywords: Creole, Mauritian society, Île de France, Hindu religion, Muslims, General population, Abolition Act

\section{Proceeding}

This article closes a work carried out under a research agreement between 1990 and 2009 in Mauritius where I was placed at the disposal of the Mahatma Gandhi Institute (MGI) to implement a joint program between the Research Institute for Development (IRD) And the Mauritius Research Council (MRC), which resulted in the completion of two post-graduate diplomas(DEA) at the EHESS in Paris, two PhD at INALCO also in Paris and a book "Mauritian Hinduism in Globalization: Indian folk cults and scholarly religion" that I co-published with Pavitranand Ramhota, one of the program's researchers.

I chose to present the creole issue in Mauritius in the same way as I have used it in my research. The ambiguity, if not the blurring of the meaning of this term, has led me not to use it at all. I replaced it with the concept of autochthony, although the Mauritian settlement did not produce a myth of origin. The first part deals with the constitutional categories of the population and their lack of clarity to describe the Mauritian reality. The second part evokes the transition from the French colonial hierarchical and patrimonial model to the British bureaucratic legal model which is at the root of the ambiguity in the practice of the term "Creole". The last part is epistemological. It integrates the human experience of research, the main purpose of which was to reach the internal modes of communication of society. I understood that the multiethnic Mauritian society remained blocked, completely closed to any "symbolization of the foreigner in internal relations". This withdrawal into isolation refers in any case to the continuity of the domination by the colonial state during the passage of the French colony to the English colony after the Paris Treaty of 1814. Julie Peghini, author of the book published in October 2016 "Dream island, real island: multiculturalism in Mauritius" has identified the often used term "nou ban Mauriciens" (we are all Mauritians) in relation to foreign relationships, referring to "noubanisme" as the ordinary way of all Mauritian to isolate themselves from the outside world, whatever their origin or the conditions of their installation on the island.

\section{Evolution of classification constitutional categories: the words to express it}

It was in 1833-1835 that the laws of abolition of slavery were officially adopted in Mauritius while the sugar plantations began, which became generalized from the $1850 \mathrm{~s}$. At that time, the country's economy moved from long-distance trade to sugar monoculture, while the island, formerly "Île de France", a country under French colonial rule became "Mauritius", a British colony. The period of transition from large-scale trade to the sugar economy was concomitant with the change in the pattern of exploitation from slavery to wage labor in a new context of English colonization. The economic and social differences of the former French slave-colony, consisting essentially of whites, free colored people and former slaves, were represented by the constitutional categories of European, "free colored", free of color and" slaves". From 1830 to 1851, these cleavages from
Volume 3 Issue I - 2018

\author{
Suzanne Chazan Gillig \\ Department of Anthropology, France
}

Correspondence: Suzanne Chazan Gillig, Department of Anthropology, France, Email suzanne.chazan@orange.fr

Received: July 16, 2017| Published: January 24, 2018

the French period did not concern the former slaves who had been emancipated since 1833-1835. The former free men of color were then associated with the Europeans into the category "European \& FC." The apprentice category was formed, composed mainly of Tamils and colored people residing in Port Louis and in the various cities of Mauritius. Then, from 1861 to 1881 , the official social classification was reduced to two categories, those of "General population" and "Indians". This was also the period of land fragmentation called by Richard Allen "Petit et Grand Morcellement". The Indians bought many parcels of land often on credit from the kalimai associations established on the former mill estates or from Indian investors such as Gudjadhur. It was also the period where compensation was provided to former masters, owners of slaves during the French colony. In 1891 the census again recorded three categories of classification: "general population" existing since 1846, the new category "Indo-Mauritians" and the "Indians". In 1901 at the beginning of the $20^{\text {th }}$ century the administration no longer distinguishes the "general population" and returns to the first category "Europeans" this time associated with the Métis under a category of "European and mixed" Meaning European and mixed race and not the free men of color of the past. The word "Métis" is for the first time mentioned at the same time as the word "Africans", a distinction coined given the large number of people of color released by the slavery abolition act, these slaves supposed to be of African or Madagascan origin. However, only 543 positive responses were identified in this new category of census in 1901. This low rate was linked to the persistent stigmatization of the former slaves freed by abolition. In spite of the abolition act, former slaves emancipated by law were always negatively perceived by public opinion. The too small number of replies related to this origin led the Administration to abandon this distinction. From 1911 to 1931 the classification of "general population" was fixed as was that of "Indo-Mauritians", a population of resident Indians differentiated because they had renewed their employment contract several times and that certain groups of families already had children born on the spot. They were then distinguished from newcomers called "Indians" or "Chinese" depending on the country of origin of the migration. The "Indo-Mauritian" category differentiated from the newcomer Indians was established for more than 60 years, from 1891 to 1952 . From 1944 to 1952, all Indians became "Indo Mauritians". From 1962 to 1983 is added the new category of Indo-Muslims or "Muslims" who are differentiated from the "Indians" while the category of "IndoMauritians" disappears in favor of that of "Hindu". There are again four categories of classification, and religious distinctions become the single criterion of differentiation: "General population" implies Catholics, "Hindus", Hindu religion, "Muslims" Muslims, and 
Buddhists "Sino-Mauricians". Note that when the category "Chinese" appears, the Indians have all become "Indo-Mauritians". Indian migrations declined considerably from 1901. They stopped in 1911.

At the present time, the term "Creole", still less that of "community", are still not really elucidated. It is well known that the so-called "communities" have followed the political social order of the new English colony. The comment made by Christopher in his article published in 1992 states that at each census the debates in parliament were aimed at fixing the criteria for adjusting classification categories to the reality of the division lines of society. Each census was an opportunity to review these categories of censal classification. The author concludes with Adele Simmons Smith that "the communities played a role in the constitutional development of Mauritius when it was mobilized to build its independence". Adèle Simmons-Smith herself affirmed that "the Mauritian political parties have been mainly supported by the communities". I would say that since the beginning of the 20th century, when the sugar mills were concentrated and modernized, the representation of origins was no longer the only reference of the distinctions produced. They were inscribed in the new framework of the division of local labor, distinguishing the "workers" with an Indian majority, from the domesticity composed mainly of people of color called "Creoles" in that they were people of color formerly slaves. Such was the definition of the Creole term, which was applied only to the rural, black population of Mauritius.

The English civil servants first had a vague representation of the Creole term to the point of having registered the same qualifier on behalf of the former white elite and mulatto of the Île de France, a category of population that traveled from the colony to the European countries, possibly for trips around the world. These trips were frequent. They included domesticity. The lists of travelers leaving or arriving from the boats in the colony are classified year by year in the Mauritius Archives in the Z2D series. At the beginning of the colony the vocabulary was not yet definitely fixed in census categories. For the representatives of the English administration, Creole meant the elite of the colored people and the whites, former "concessionaries", great landowners, or businessmen, mostly natives of the colony, paying taxes who had signed the "oath of allegiance" to the Queen of England. Even though it was the mode of the "gentleman agreement" that prevailed in the transfer of power from one metropolis to another, submission was real in a general context of institutional continuity representing the former colonial state.

Later and very gradually, the representations followed the vagaries of the censorial distinctions where the Creole term never appeared as such in the classification categories. It could have been used several times to distinguish people of color from whites giving credit to the meaning most often given to the Creole term, that of natives of the colony. Finally, the term Creole recalled the discrimination made in Mauritius by the new colonial power between the population already present in the colony and the new entrants. For the English administration, the islands population was necessarily Métis, by designing it 1901 as "European and mixed". Finally, the Creoles would be "all those who are not white". However, the opposition of color white / black has been the main criterion of the social and economic differentiation of the French colonial world. The distinction by color would have been perpetuated by the socialization and the education of the children. It would have been guaranteed by the practice of strict endogamy which simultaneously controlled the realestate assets organized around the sugar mills. The French colonial elite was a real "republic of cousins", which was subjected to the new metropolis of London. This after a reconfiguration period linked to the events that had deeply affected it-the transfer of power from the metropolis of Paris to London, the abolition of the slave trade and the compensation scheme of the former owners of slaves. As a result, the submission of some led to that of the others. The meaning of the Creole term was reversed and no longer meant the former French colonial elite; however the former slaves were far from being liberated by the slave abolition acts because they did not benefit from a status in the new colonial bureaucratic order. Subsequently, the former French colonial elite, reconstituted and sometimes associated with foreign investors has regained its nobility above all expectations by the fact of their economic success. The performance of sugar companies in the competitive world of the new global sugar economy was such that it became the emerging social class of the new British colony. Its "class" position was both marginal and central. I would compare it to the position of the "corps constitués" (corporate bodies) of the French administration. Indeed, various interviews with multiple informants from various social positions indicated that the UK administration has operated with very few staff on assignment. The latter controlled the colony's "affairs" in an indirect and differentiated mode. The hierarchy of sugar companies has been the spearhead of sugar production which has been covering up to $99 \%$ of the local economy. The English legal and bureaucratic administration has focused on the control of monetary and commodity exchanges. The Creole term available but never used by the English administration followed the path of a process of in differentiation as was the term "general population" which had no precise meaning in the new colonial order whose mode of management was indirect, based on the mediation of the sugar-estates power with regard to production, whose status was that of a full autonomy in a successful business. In this context, the term Creole is the product of the negation of negation: that of internalization of submission on the one hand, and of a mediation of power relative to the affairs of the colony on the other. They were the "voiceless", excluded from the system of power ultimately instituted in the contemporary model of parliamentary representation. One can go so far as to think that the over-determination of the former colonial population by the use of the term "general population" which prevailed was the visible sign, the indicator of the economic nature of the power once separated from those social relations which were its constituent components. Let us examine these real historical relationships which have founded the new colony power.

\section{The true meaning of words: formal legal liberation, real domination}

Words by their weight and meaning are there to tell that all those who have not been emancipated by their former masters, those who have been legally released from slavery solely by the legal laws of abolition of the slave trade laws promulgated by the new colonywithout having acquired a constitutional status in the new state, remained stuck to their former status as slaves. The updating of the dominance they suffer focused on the deepening of the symbolic meaning of the classification categories over time in the new colony. What is the meaning of the appearance/disappearance of certain classification categories? What remains unsaid about a story being kept hidden behind the words to express it? The term that included all those who were once free or emancipated by their masters in the former Île de France, this "general population" considered to be of European origin until 1846 and 1901 at a time when the sugar economy was modernizing has led to the reversal of the meaning of 
the "Creole" term which finally has designated the former slaves who were legally freed in $1833-1835$ by the Abolition Act. Can it be said, however, that the former slaves who had not been liberated by their former masters at the time of French colonial rule were truly liberated in 1833-35 by the Abolition Act in a country with a legal political and bureaucratic model that did not grant them any constitutional status? Legally released, of course they were but not contractually. What is the unsaid in this history of variation of terms generating collective identities? It is obviously not by chance that this was an institution whose sovereign function has been to prepare the scales of status of the local society, including the most recent emigrant population. The words by which the local social groups were instituted or, on the contrary, denied reveal the unsaid of this local history within the great international history in the making.

The absence of the Creole term which might have distinguished the natives of the two colonies, the former French colony and the new English one, its being replaced by the terms "free colored" or "mixed", the successive association of these two words to the term "European", inform upon the reality of the international relations that took place at the time of the transfer of colonial power. Until 1845 and in 1901, the former French colonial elite was called European. Let us reconcile the geopolitical and economic context in which the territorial division of the countries bordering the south-west Indian Ocean took place. Of course, there was rivalry, oh how much, between France and England for the control of the Indian subcontinent and Madagascar. There have been local wars for the sharing of empires. Beyond these "sea adventures", these maritime victories, there was an agreement at some point between the belligerent European countries dominant under the "triple alliance", France, England and Holland. The purpose of this alliance was to unite the three companies of the Indies into a single "Indian Company." At the same time the Cape route was opened and the state bank was created Law system, opening the possibility of investment by the new united "Compagnie des Indes". The chosen census term of "European" symbolizes the power of the metropolises being organized in the north of the planet, while to the south a vague maritime victory of England over France seemed to be the cause of the changes of government. This narrow representation of the stakes of local power has masked the real territorial, political and financial redistribution taking place at this time of the division of empires: the relations of the European world with the islands in the south of the planet have transformed them into monoculture plantation economies while the financial system was gradually internationalized. No racial, ethnic, or community criteria can explain the new social-political order that was taking place in the British colony. We are far from Creole, African or Indian identities. That is why I have sought a new language that would less affect the social reality being reconstructed through periodical censuses.

\section{Differential model of colonial power: autochthony, creolity}

The "Creole" term finally designated in Mauritius the former slaves who were emancipated by the Abolition Act promulgated by the British colony. The "Mauritian Creoles" are today mainly part of the rural population. From the loss of the political function of the former elite of the island of France, known as the "Creole society" which paid taxes, until the abolition of the slave trade, there was a major disruption of the old colonial society. Previously divided into classes of workers, agricultural laborers, and servants, the former French colony was struck at the heart of its system of exploitation, since most workers, once freed slaves had chosen to leave the plantations of their former masters. Whether we look at society from above, from its former dominant elite, subjected to the new colonial administration or from below on the side of the workers, the term "Creole" is linked to the model of colonial power which has no other meaning that the new reality of dependency, even if, with time, thanks to the secrecy of business and to the investments now possible in the sugar estates as a result of the compensation of the former slave owners, the old dominant company recomposed has emerged socio-economically speaking. It is the former slaves, or supposed to have been such, who paid the high price of modernity, through which a sugar bourgeoisie of business was established whose success in social and economic terms would not have been possible without the existence of a legal alliance with the local government of the colony. That is why I compared the status of sugar estate in the new British colony to that of the "corps constitutés" (corporate bodies) of the state in France. There has been a political re-rooting of the French colonial elite qualified as general population in the censuses.

Let us consider once more the choice, revealing, made by the statistical service to distinguish the group of the first emigrants called "old migrants" who were a statutory group with the "appellation controlee" Of "Indo-Mauritians" from 1891 to 1952 because they had renewed several times their employment contract so that they had children born on the spot. The reason given by our informants has been linked to the need to protect them from the possible competition they might have suffered by the new waves of migrants, those who had become small or even large Indian owners at the time of the land fragmentation between 1860 and 1880 . The question then arose as to why those who were called people of color, free or former slaves of the colony of the former Île de France who had also generated native-born children did not benefit from a status equivalent to the Indo-Mauritians between 1891 and 1952 which would have protected them more effectively from the loss of the little they had in small plots of land, houses etc. The census was indeed a political tool designed to order power under the form of democratic parliamentary representation. The positions of power have been exercised elsewhere among the existing representational games in everyday life and work.

To reconstitute this unsaid part of history, to give it its own rationality and to be able to write about it, I chose the term "autochthony" which is not a concept but an operative mode, a mediator in the writing process so as not to over-emphasize certain social relationships by calling them too rapidly a "community". Was the group designated by the general census as the "general population" a community? Obviously not! From this"appellation controlee" is issued the ambiguity, the ambivalence of the "Creole" term. On the other hand, the term "Creole" has a precise meaning for those who had a comparable experience of domination, whose common past is an integral part of the singularity of their Mauritian experience. The term "autochthony" in the meaning I have given has made possible the interstitial questioning practice in order not to over-determine the meaning of a word by the use of another word maladjusted to the social phenomena that have been brought to light. There were obviously inequalities instituted by the choice of words to designate the groups which had right of citizenship in the British colony. Their power value was all the more clear in that the quantification of the categories of population had this character of scientific method. This is what committed me to describe the mechanisms of community production of autochthony. The Indians could differentiate themselves within the sugar establishments where they worked in reference to their 
tutelary divinities whose traditions, songs and ceremonial practices they had preserved. I became aware of a collective relationship of the Indians to the land in the camps or on the parcels of cane fields, where they worked in bands under the authority of a sirdar, an Indian foreman who managed the manpower and paid the wages of the bands of workers under his responsibility. My study of the popular cults of the kalimaiis, carried out in collaboration with Pavitranand Ramhota, mainly on the east coast, but also on the outskirts of the cities of Mahébourg and Port-Louis, highlighted the first religious and family differentiations which were produced where strict endogamy by fathers has been the rule. Networks of endogamous families have developed through the popular cults that have been established on the land of registered properties, officially given by the bosses to the coolies for their cults. All notarial acts of the kalimaï lands were recorded and studied. There is no doubt that these deeds have opened up access to the ownership of land put up for sale in the period of the "Grand et Petit Morcellement" of property. The term "community" has gained a more and more precise social meaning as the description of the relationships established by the local groups, forming networks of families and endogamous groups in the camps of the various sugar estates where the Indians have been distributed. Groups belonging to the same kalimai were clearly communities. While the community groups have been historically and socially defined within the Indian population, the Creole term has remained blocked by its systemic character and constantly referred to the society of slavery plantation evoked virtually which highlighted the idea of a patrimonial power focused on the biological reproduction of white families. This type of power was described in an abstract way by my informants, the Creoles of some villages, without any specific statutory reference other than the historical vicissitude that linked them to the "general population" .They would today be the "voiceless" if there were not various parties to instruct their position on the occasion of the elections, if there was not a local press expressing their demands and difficulties. I reversed the challenge of the "Creole Issue" and in doing so I had to realize that it was inversely symmetrical to the ethnic proposition supported by the government. This question which has been dealt with in our book is another matter. I prefer to approach the epistemology that gave me access to the internal communication modes of contemporary society.

\section{Epistemology of research}

To update the modes of internal communication of a given society, to understand from the inside the modes of building social relations requires a work at the periphery of things, to raise the social relations established on the ground of the surveys through personal relationships and retroactively highlight the research positions assigned to me by my informants or that I have deliberately taken, which is what the investigation journal tells us. This development of the place of the researcher in the investigation refers to an epistemological practice that is connected to the issue that constantly put by Gérard Althabe "who am I for my informants?" Ferdinando Fava, one of his doctoral students, reported on the unprecedented epistemology as taught by Gérard Althabe at EHESS. His book published in 2014 clearly shows what Gérard Althabe called "La démarche" and highlights the ethnological method put into practice on the field. The teaching of Althabe advocated the exercise of critical thought at all moments of research, whether it be field practice or writing that is the product of it. The three levels of interpretation that characterize Gérard Althabe's epistèmê are in the order of "building social bonds", "ethnographic scene" and finally, the great issue of the subjectivity tested in the inquiry. Closely related to Gérard Althabe when I arrived in Madagascar in 1967, I quickly realized that this approach to the field was a great innovation allowing the retroactive processing of data of a subjective nature in a survey, those that are recorded on a daily basis in a field notebook, where the left-hand page initially left empty would indicate the in-situ and posterior comparative analyzes of the survey data.

The research work carried out in Mauritius was based on this methodological orientation in ethnology. It had been opened by Georges Balandier on the African countries, when, in contrast to the structuralism of Levi Strauss, he gave an epistemological value to the content of human experience in an inquiry. The intellectual operation by which the subjectivity of a research is transformed into an object, this unpublished part of a field research comes from a different perspective on someone other than us, which is combined with a global interpretation of the events that occurred in the surveys, because any update catches the specificity of the socio-historical and cultural relationships to be identified. In other words, the construction of knowledge in ethnology proceeds from a questioning of otherness in the situations of inquiry revealing the relations of the local to the global, of the way in which they meet in the events of the investigation. From the nation of "colonial situation" (Balandier) Gérard Althabe has moved on to "social situations" experienced in the investigation. He has implemented a rigorous discipline of analysis by which one can see and understand the social relations objectified on the spot. This empirical conception of knowledge in ethnology meets the work of authors such as Gold and Adler, who considered in the 1960s that fieldwork, was an integral part of the production of knowledge in ethnology.

While Georges Balandier was at the origin of the concept of "colonial situation" at the time when Croziers spoke of "Third World", Gérard Althabe theorized the concept of "situation of inquiry", giving rise to a general epistemology associating issues arising from the survey data as set out in the book by Ferdinando Fava. It was not the concepts of social psychology that were at the origin of the epistemological orientation of Gerard Althabe, whose philosophical culture was, from the outset, marked by the youth debates he shared with his childhood friend René Lourau. For his part, he followed his own path by resorting to phenomenology, especially in Madagascar, where he perfectly distinguished the in-itself and the for-itself in the description he made of the events to which he participated while he differentiated the spontaneous events issued from the society under study, from the events provoked by the anthropologist. From this distinction were made the concepts of "symbolic actor" and "verbal consciousness" in relation to the analytical and critical treatment of interviews organized before, during and after the events, helped by the daily narrative of field activities.

If I am raising the method being used here, it is because it deals with a radical critique of the sources of inquiry similar to those of Georges Balandier and Gérard Althabe. This return to the roots of the survey data make explicit the choice of the subjects of publication that led to the release of our common work with Pavitranand Ramhota with which I developed an intellectual companionship after the defense of his $\mathrm{PhD}$ in 2004. Several general topics were discussed before the book was released in 2009. On the nature of colonial powers, the status of the cultural in the new political-economic order after the Paris Treaty of 1814, the birth and development of Mauritian capitalism which led the country to align itself with the newly industrialized countries PNI). I only was able to write when I considered the Creole world and the community-based world in relation to the two forms 
of colonization that have generated political models that everything separates: the centralized French model, hierarchical, patrimonial and the Anglo-Saxon model of legal, bureaucratic type that cultivates invisibility and the practice of secrecy. I wanted above all to show here the importance of the weight of words and their adequacy to the reality studied in the practice of social sciences.

\section{Acknowledgements}

None.

\section{Conflict of interest}

Author declares that there is no conflict of interest. 